\title{
Seeing past the red: flawed IUCN global listings for sea turtles
}

\author{
Matthew H. Godfrey ${ }^{1,2, *}$, Brendan J. Godley ${ }^{3}$ \\ ${ }^{1}$ North Carolina Wildlife Resources Commission, 1507 Ann Street, Beaufort, 28516 North Carolina, USA \\ ${ }^{2}$ Nicholas School of Environment and Earth Sciences, Duke University Marine Lab, 135 Marine Lab Road, Beaufort, \\ 28516 North Carolina, USA \\ ${ }^{3}$ Marine Turtle Research Group, Centre for Ecology and Conservation, School of Biosciences, University of Exeter, \\ Cornwall Campus, Penryn TR10 9EZ, UK
}

\begin{abstract}
The Red List of Threatened Species, produced by the International Union for the Conservation of Nature and Natural Resources/World Conservation Union (IUCN) classifies the global populations of all 7 sea turtle species, except the flatback Natator depressus, as Endangered or Critically Endangered. However, the IUCN Marine Turtle Specialist Group (MTSG), which carries out the assessments for the IUCN, is experiencing internal debate over the relevance and usefulness of such statements. Assigning a distinct Red List category to the global population, as a single management unit, does not capture the reality of regional and local populations that tend to have different (positive or negative) trajectories. From a technical viewpoint, setting the time scale for assessment at 3 generations, which is 60 to $100+$ yr for sea turtles, means few reference points are available for quantifying past changes in abundance. Moreover, it hardly establishes a sense of urgency for action to prevent future changes over long time scales. The application of current Red List criteria, resulting in flawed categorizations, creates problems of credibility. When a species that may number in the millions in an ocean basin is classified as being at the same 'very high risk of extinction in the wild,' as a species represented by just a few individuals, there is something fundamentally wrong with the assessment system. We suggest that MTSG members desist from using the current Red List criteria to generate implausible global assessments of extinction risk and instead concentrate their efforts on developing more realistic and credible criteria, perhaps for application at the regional level.
\end{abstract}

KEY WORDS: Extinction risk $\cdot$ Status $\cdot$ Marine turtle $\cdot$ Red List $\cdot$ IUCN Resale or republication not permitted without written consent of the publisher

\section{INTRODUCTION}

The Red List of Threatened Species (www.redlist. org) of the International Union for the Conservation of Nature and Natural Resources/World Conservation Union (IUCN) is the most comprehensive catalog of the relative conservation status of species (Rodrigues et al. 2006). The Red List has developed and refined criteria that are to be universally applied. All sea turtle species, except the flatback turtle Natator depressus, are currently considered endangered or critically endangered on a global level according to the Red List (Seminoff \& Shanker in press). With minor modifications, these species have been listed as such for several decades (see Table 1 for timeline). The Marine Turtle Specialist Group (MTSG), the volunteer organization charged by the IUCN with applying the Red List criteria to sea turtles (Davis 2005), is in the process of updating assessments for olive ridley turtles (Lepidochelys olivacea (Abreu-Grobois \& Plotkin 2007, also submitted to the IUCN) and hawksbill turtles Eretmochelys imbricata (Mortimer \& Donnelly 2007, also submitted to the IUCN) (Hutchinson et al. 2007).

Questions about the relevancy of a single global category of extinction threat for sea turtles were raised over 2 decades ago (e.g. Mrosovsky 1983, Pritchard 
rion A requires quantification of the decline in abundance that has occurred over '10 years or 3 generations, whichever is longer'. Thus the baseline reference point for sea turtles, which are long-lived, can be as long as 60 to $100+$ yr before present (see Seminoff \& Shanker in press). That is, in some cases quantitative abundance data from as far back as the late 19th century are needed. Because hardly any such data exist, recent sea turtle assessments have relied on historical reference points that are at best crudely derived, sometimes using circular arguments assuming specific rates of decline. When compared to current estimates of the abundance of wild populations, the extent of the decline that has really taken place in the global population is at best vague and at worst speculation. There are simply not enough reliable data available on historical levels of sea turtle abundance around the world, making it impossible to scientifically apply the Red List criteria with confidence. The recent global assessments on sea turtles generated by the MTSG (Table 1) are not sufficiently grounded in real data to be considered reasonable.

\section{FLAWED OUTPUT USING FLAWED CRITERIA}

Despite detailed attempts to apply the Red List criteria to sea turtles, clearly inappropriate categorizations have been produced. For example, green turtles have been listed as globally Endangered, based on Seminoff (2004a), which according to version 3.1 of the Red List criteria means the global population is facing a 'very high risk of extinction in the wild'. 'Extinction' itself is described as 'there is no reasonable doubt that the last individual has died' (www.redlist.org). Yet there are few, if any, conceivable scenarios that could lead to every single green turtle disappearing from the world's oceans in the foreseeable future. Broderick et al. (2006) reviewed the available data and showed that 6 of the 8 largest green turtle rookeries in the Atlantic were stable or increasing, and estimated that, when juveniles are included, the individuals from these index sites totaled between 2.2 and 2.6 million.

The leatherback turtle was listed as Critically Endangered in 2000 (Sarti-Martinez 2000), and at that time this category (version 2.3) was defined as 'facing an extremely high risk of extinction in the wild in the immediate future' (www.redlist.org). Yet, a recent overview of the status of this species suggests that the majority of the populations in the Atlantic Ocean are stable or increasing in size (TEWG 2007). Although it is clear that numbers at some sites in the Pacific have suffered massive and serious declines, there are stable populations of leatherbacks totalling $>14000$ individuals nesting annually in the Atlantic. Even the recently submitted global assessment of the olive ridley turtle has rated the species as Vulnerable (Abreu-Grobois \& Plotkin 2007), which is defined as facing 'a high risk of extinction in the wild.' Yet there are nesting sites in the Indo-Pacific that have $>1$ million nests per season (Abreu-Grobois \& Plotkin 2007). Again, there are few if any scenarios through which olive ridley turtles could be removed from the world in the foreseeable future.

This mismatch of the risk of extinction predicted from applying the criteria and that predicted from a common sense evaluation of status, has been noted by other authors (Meylan \& Donnelly 1999, Webb \& Carrillo 2000, Mrosovsky 2003). Yet, the MTSG continues to invest a great deal of effort in trying to use the extant Red List criteria for sea turtles, while at the same time agreeing that they are flawed.

\section{ACTION}

We suggest that the MTSG desist from using the current Red List criteria to generate global assessments of extinction risk for sea turtles. This would help avoid the mismatch between perceived risk categorization of species and the real-world status of regional populations. It would also alleviate the need to allocate research resources to generating historical reference points with spurious levels of accuracy and precision, and no application to management of today's populations. We do not advocate abandoning attempts to assess risk of extinction for sea turtles. We believe that sea turtles are conservation-dependent species, and should be managed accordingly. They do not, however, need to be on the brink of extinction to deserve our focus.

Regional assessments of extinction risk, based on alternative criteria, could help prioritize those sea turtle populations that are in greatest need of conservation. Indeed, the benefits of working on threatened species at national or regional levels have been highlighted by others (e.g. Rabb 1996, Gärdenfors 2001), and the IUCN has provided guidelines for conducting Red List assessments at the regional level, even if the results are not included in the official Red List (IUCN 2003). However, the problems associated with the Red List criteria applied at the global level are carried over to the regional level, so simply shifting levels is not a quick fix. Revised criteria for assessing risk of extinction for sea turtles are needed. They should not rely on unobtainable historical data; rather they should emphasize recent, current and perceived threats in the near future. This could be achieved by relying on a shorter time framework, and abandoning '3-generations' with these long-lived species. We challenge 
MTSG members to research and test criteria that match realistic likelihoods of extinction for regional sea turtle populations.

The only mechanism within the extant IUCN Red List portfolio that may have utility is Criterion E: 'Quantitative analysis showing the probability of extinction in the wild is at least $\mathrm{x} \%$ within $\mathrm{y}$ years or $\mathrm{z}$ generations, whichever is longer (up to 100 years)' (www.redlist.org). The threshold of extinction probability changes for each classification of extinction risk (50\% for Critically Endangered, 20\% for Endangered etc.), as do the number of years (10 for Critically Endangered, 20 for Endangered etc.) and generations (3 for Critically Endangered, 5 for Endangered etc). Such approaches are far more likely to result in plausible listings with real, defensible utility, although the multiple generation time frames for the modeling exercises might introduce greater uncertainty. For additional suggestions of alternative methods for assessing risk of threat in sea turtles, see Seminoff \& Shanker (in press).

Although we recommend that global Red Listing activities based on the current criteria be abandoned by the MTSG, we suggest that past global assessments have not been wasted effort. Indeed, the compilations of data on the current global status of marine turtles in the global assessments (e.g. Seminoff 2004b, AbreuGrobois \& Plotkin 2007, Mortimer \& Donnelly 2007) are a valuable and useful source of information on current numbers of nests and nesting females in specific populations around the world, and they highlight any remaining gaps in knowledge. These kinds of data dovetail nicely with parallel work being done by the MTSG, in partnership with other NGOs and partners, in generating information for the State of the World's Sea Turtles' initiative (see www.seaturtlestatus.org). In fact, it is surprising that these 2 MTSG projects apparently have not yet worked in tandem. Generating an exhaustive referenced database on current population levels is an essential step for assessing the true status of sea turtle populations.

Acknowledgements. The manuscript benefited from discussions among MTSG members on the group's listserv and the constructive comments on an earlier version of the manuscript by A. Broderick, N. Mrosovsky, P. Pritchard, D. Roberts, J. Seminoff, K. Shanker, and G. Webb.

\section{LITERATURE CITED}

Abreu-Grobois A, Plotkin P (2007) MSTG global assessment of olive ridley turtles for the IUCN Red List. Available at: www.iucn-mtsg.org/red_list/ (accessed on 31 August 2007)

Baillie J, Groombridge B (1996) 1996 IUCN Red List of Threatened Animals. IUCN, Gland
Bowen BW, Karl SA (1996) Population genetics, phylogeography, and molecular evolution. In: Lutz PL, Musick JA (eds) The biology of sea turtles. CRC Press, Boca Raton, FL, p 29-50

Broderick AC, Frauenstein R, Glen F, Hays GC and others (2006) Are green turtles globally endangered? Glob Ecol Biogeogr 15:21-26

Davis FR (2005) Saving sea turtles: the evolution of the IUCN Marine Turtle Group. Endeavour 29:114-118

Gärdenfors U (2001) Classifying threatened species at national versus global levels. Trends Ecol Evol 16:511-516

Groombridge B (1982) The IUCN Amphibia-Reptilia red data book, part 1: Testudines, Crocodylia, Rhynocehapalia. IUCN, Gland

Groombridge B (1994) 1994 IUCN Red List of Threatened Animals. IUCN, Gland

Groombridge B, Luxmoore RA (1989) The green turtle and hawksbill (Reptilia: Cheloniidae): world status, exploitation and trade. Secretariat of the Convention on International Trade in Endangered Species of Wild Fauna and Flora, Lausanne

Hutchinson BJ, Mast RB, Pilcher NJ (2007) IUCN-SSC Marine Turtle Specialist Group quarterly update. Mar Turtle Newsl 117:13-14

IUCN (1990) 1990 IUCN Red List of Threatened Animals. IUCN, Gland and Cambridge

IUCN (2001) IUCN Red List categories and criteria: Version 3.1. IUCN Species Survival Commission. IUCN, Gland and Cambridge

IUCN (2003) Guidelines for application of IUCN Red List criteria at regional levels: Version 3.0. IUCN Species Survival Commission. IUCN, Gland and Cambridge

IUCN-CMC (IUCN Conservation Monitoring Centre) (1986) 1986 IUCN Red List of Threatened Animals. IUCN, Gland and Cambridge

IUCN-CMC (IUCN Conservation Monitoring Centre) (1988) 1988 IUCN Red List of Threatened Animals. IUCN, Gland and Cambridge

Mast RB, Seminoff JA, Hutchinson BJ, Pilcher NJ (2006) The role of the IUCN Marine Turtle Specialist Group in setting priorities for sea turtle conservation. Mar Turtle Newsl 113:16-18

Meylan A (1998) Hawksbill turtles still endangered. Nature 391:117

Meylan AB, Donnelly M (1999) Status justification for listing the hawksbill turtle (Eretmochelys imbricata) as Critically Endangered on the 1996 IUCN Red List of Threatened Animals. Chelonian Conserv Biol 3:200-224

Mortimer JA, Donnelly M (2007) Marine Turtle Specialist Group 2007 IUCN Red List status assessment, hawksbill turtle (Eretmochelys imbricata). Available at: www.iucnmtsg.org/red_list/ei/ (accessed on 31 August 2007)

Mrosovsky N (1983) Conserving sea turtles. British Herpetological Society, London

> Mrosovsky N (1997) IUCN's credibility critically endangered. Nature 389:436

Mrosovsky N (2000) Sustainable use of hawksbill turtles: contemporary issues in conservation. Issues in Wildlife Management, No. 1. Key Centre for Tropical Wildlife Management, Darwin

Mrosovsky N (2003) Predicting extinction: fundamental flaws in IUCN's Red List system, exemplified by the case of sea turtles. Available at: http://members.seaturtle.org/ mrosovsky/

Pilcher N (2004) To fix or not to fix? A review of Mrosovsky's 'Predicting extinction'. Endang Species Res 1:49-50

Pritchard PCH (1987) The survival of sea turtles: Are they 
endangered, threatened, or what? Report for the Marine Turtle Specialist Group. Available at: www.iucn-mtsg.org/ red_list/docs/Pritchard_1987_MTSGReport.pdf

Rabb G (1996) Foreword. In: 1996 IUCN Red List of Threatened Animals. IUCN, Gland, p 6

Rodrigues ASL, Pilgrim JD, Lamoreux JF, Hoffmann M, Brooks TM (2006) The value of the IUCN Red List for conservation. Trends Ecol Evol 21:71-76

Sarti-Martinez AL (2000). Dermochelys coriacea. In: 2006 IUCN Red List of Threatened Species. Available at: www.iucnredlist.org. (accessed on 5 September 2007)

Seminoff JA (2004a) MTSG global assessment of green turtles (Chelonia mydas) for the IUCN Red List. IUCN Species Survival Commission, April 2004. Available at: www.iucnmtsg.org/red_list/cm/MTSG_chelonia_mydas_assessment _april-2004.pdf

Editorial responsibility: David Roberts, Surrey, UK
Seminoff JA (2004b) Sea turtles, Red Listing, and the need for regional assessments. Mar Turtle Newsl 106:4-6

Seminoff JA, Shanker K (in press) Marine turtles and IUCN Red Listing: a review of the process, the pitfalls, and novel assessment approaches. J Exp Mar Biol Ecol

S\&PS (Standards and Petitions Subcommittee) (2001) Red List petitions results. Species 36:31-34. Also available at: http://intranet.iucn.org/webfiles/doc/SSC/SSCwebsite/ species_/species36.pdf

TEWG (Turtle Expert Working Group) 2007. An assessment of the leatherback turtle population in the Atlantic Ocean. NOAA Technical Memorandum NMFS-SEFSC-555. Available at: www.sefsc.noaa.gov/seaturtle techmemos.jsp

- Webb GJW, Carrillo E (2000) Risk of extinction and categories of endangerment: perspectives from long-lived reptiles. Popul Ecol 42:11-17

Submitted: October 2, 2007; Accepted: November 6, 2007 Proofs received from author(s): February 21, 2008 